\title{
Impact of Human Resource Management Practices on Organizational Performance \\ (A Case of Nepal) \\ Gopal Man Pradhan
}

Associate Professor

Tribhuvan University

\begin{abstract}
HRM practices in Nepalese organizations are undergoing continual transition, moving from former personnel concepts to modern HRM policies and strategies. This study focuses on assessing the human resource practices in the manufacturing and service sector institutions in Nepal. This study also attempts to find out the relationship between the adoptions of such practices in their performance. The correlation results suggested that there is negative association between HRM practices and employee turnover whereas there is positive association between HRM practices and productivity. The regression result suggested that there is a negative association between HRM practices and employee turnover whereas there is positive association between HRM practices and productivity. At present many Nepalese business organizations are found using team based job design that fosters the specialization as well as the synergy in the team assignment.
\end{abstract}

Key words: HRM practices, employee turnover, productivity, team work, descriptive search,

\section{Introduction}

We are living in an era where the business world has become a village and the business organizations are facing cutthroat competition from around the globe. The emerging global competition, focus on customers, speed and flexibility have created challenges in all types of organizations in modern market economy. The competitive forces that managers face today will continue to confront in future demand of organizational excellence. The effort to achieve such excellence are through the fundamental elements of the human resource management that is focusing on learning, quality, team work 
and reengineering which are driven by the way organization get things done and how they treat their people.

Regarding the human resource management in Nepalese business organizations, very few researches have been made by linking the business strategy, human resource management and human resource outcome. Adhikar(2004) suggests that there have been no significant change at firm level HR polices and practices even after the changes in the economic and political priorities in the last decade Nepal is still at the initial stage of the development of human resource management. Human resource planning and practices are not in the priorities of Nepalese managers.

There are several approaches given by the scholars in the field of human resource management and its relationship with performance. Guest (2002) prescribed three dominant approaches in defining the key way in which human resource management might enhance corporate and the strategic fit model. When it comes to developing nations like Nepal the role of human resource is visible only in those organizations, which either are knowledge organizations or are technology intensive organization.

\section{Statement of Problems}

The initial research on HR practices and organizational performance was, unsurprisingly greeted with much enthusiasm by academics and practitioners alike, and the figures appear impressive and authoritative (Richardson and Thompson, 1999). However, researchers (Huselid, 1995; Guest, 2005) in this area have recognized some of the limitations of the research approach to date and there has been an increasing body of criticism related to early work, which was almost, completely comprised of quantitative data analyzed statistically. The criticism in relation to the assessment of HR polices and practice relates to three areas: the reliability of the data; the lack of depth and breadth in the data; and the conceptual model within which the research was carried out. 
The employee performance, which may result from, enhanced employee commitment. earlier research directly analyzed HR policies and employee performance and in many cases, a statistically significant relationship has been found(McDuffie, 1995; Arthur, 1994; Koch and McGraht, 1996). So far only Patterson et. al.(1997) and Guest et al. (2000) have analyzed productivity and quality in relation to commitment as well as in relation to RH practices. Patterson et al. (1997) did find significant relationships between employee performance and commitment and between employee performance and HR practices. However, Guest et al. (2000) found no direct relationship between HR practices and commitment and also a relationship between commitment and employee performance outcomes.

In Nepalese context, to date few studies have been carried on by some scholars linking the human resource practices with firm performance. Gautam (2003) found that Nepal has high affective commitment rather than other commitment due to the national culture. Adhikari and Muller (2001) have found that there are opportunities and challenges for a transfer of western type HRM prescriptions to developing countries. Nepalese managers and policy makers are generally not convinced about the benefits of investment in human resources. In particular, it is yet to be recognized that people should be treated as valuable assets. Nepalese researchers and academicians have not considered $t$ this field as the field of research.

\section{Research Questions}

- What is the status of the HR practices in the manufacturing and service sectors in Nepal?

- How human resource management practices effecting employee turnover, and productivity of the organization?

- How human resource management practice effecting organizational employee performance in the perspective of Nepalese manufacturing and service sectors organizations? 


\section{Research Objective}

The present study focuses on assessing the human resource practices in the manufacturing and service sector institutions in Nepal. This study also attempts to find out the relationship between the adoptions of such practices in their performance. In this context, this study attempt to achieve the following objectives:

- To explore the status on the HR practices in Nepalese organizations

- To examine the relationship between HR practices and organizational and employees performance

\section{Significance of the Study}

The innovation of new science and technology and implementation of that knowledge in business has contributed for repaid change in production, distribution and service sectors. The introductions of automation, robotics and computerization system in manufacturing sectors have brought new change in production process. Similarly, volumes of business of service sectors organizations have also been in increasing trend. These bring rapid change in the concept of human resource management and their importance. The evolution of World Trade Organization has brought both opportunity and threat for Nepalese organizations.

Majority of researchers on the RHM and performance linkage have focused in eh manufacturing sector, in the western context with a few cases with the emerging markets such as China and India. This study might give an insight on the relationship between HRM and performance in the context of least developed country like Nepal, and in service sector.

HR practices in Nepalese organizations are undergoing continual transition, moving from former personnel concepts to modern HRM policies and strategies. This trend stems from a series of societal, technological and political changes that have occurred in Nepal over the last two decades. The HR manager must cope with the influences of these changes and at the same time allow the firm to preserve and even enrich its human capital value. In such a scenario, Nepalese business organizations can remain no exception. The success of the business organization largely depends on the effectiveness 
and quality of the services that they provide to the customers. Keeping these views into consideration, this study is expected to be fruitful to explore the HRM Practices that exist in the manufacturingand service sectors and their effects on the organization and employee performance.

\section{Limitations of the Study}

The researcher is guided by appropriate research methodologies to come up with suitable findings. However, there are some notable research limitations, which are mentioned as:

- This study is based on cross sectional data, which fails to show the time lag effects of the variables under study.

- The constituents of human resource outcomes used under this study may not be equally applicable in all organizations having different context.

- The human resource practice variables used under this study may not clearly represent all organizations.

- This study is confined only to limited manufacturing and service sectors. It is therefore, the finding of this study may not represent all the business units.

- Most of the data used in the study are collected from primary sources through survey method. Therefore, the validity of the data depends upon the individual perception of the respondents.

\section{Theories of Linkage between HRM and Performance}

Early attempts to link HRM with organizational performance relied on the common sense belief that improving the way people were managed inevitably led to enhanced firm performance(Ulrich, 1997), without seeking to justify this linkage in theoretical terms. In the wake of the different research projects, it was argued $\mathrm{n}$ one review that the subject was no longer theoretical, and that a variety of different theories, including general system theory, role behaviour theory, institutional theory, resource dependence theory, human capital theory, transactions cost economics, agency theory and 
the resource based theory of the firm had been used to explain the HRM performance linkage(Jackson and Schuler, 1995).

\section{Framework of the Study}

The elements of human resource management consisting of recruitment and selection, training and development, performance appraisal, career planning, compensation, employee participation, and job description have positive impact on employee performance and performance of the organization.

Table 1

Theoretical Framework

\begin{tabular}{|c|c|}
\hline HRM Practices & \\
\hline \multirow{2}{*}{$\begin{array}{l}\text { - Recruitment and selection } \\
\text { - Training and development } \\
\text { - Performance appraisal } \\
\text { - Career planning } \\
\text { - Compensation system } \\
\text { - Employee participation } \\
\text { - Job description }\end{array}$} & $\begin{array}{c}\text { Employee and organizational } \\
\text { Performance }\end{array}$ \\
\hline & $\begin{array}{l}\text { - Employee turnover } \\
\text { - Productivity }\end{array}$ \\
\hline
\end{tabular}

\section{Nature of Research}

This study is based on primary data obtained by distributing questionnaires to selected respondents. Therefore, it is descriptive, co-relational, causal comparison type of research. In this research some selected human resource management practice variables have been taken into account for getting feedback from both managerial and assistant level employees of selected manufacturing and service sector organizations. Besides, human resource outcomes have been measured in terms of employees' turnover and productivity position of selected institutions, in this, it is tried to maintain co- 
relation and link among HRM practices variables and employees and organizational outcomes.

\section{Research Design}

The research designed adopted in this study consists of descriptive, corelational, and causal comparative research design to analysis the various issues are raised. The descriptive research design is used for the purpose of fact-finding, conceptualization, description, and operation searching for adequate information in the context of RHM practices and employee and organizational performance in Nepal. This study has also adopted correlation research design to establish the relationship between HRM practices and performance. Moreover, this is study also adopted causal comparative research design to determine the relationship between HRM practices and employee and organizational performance in Nepal. The research design adopted in this is identical as the previous researches taken place, for example Guest, 2002. HR practices build job infrastructure that can provide maximum amount of information to employee, decentralize decision making, and motivate employees to attain organizational goals (McDuffie, 1995; Wright et al., 2005)

A numbers of literature, therefore, were reviewed to see the state of HRM. The state of RHM in business firm of Nepal are analyzed based on the different types of HR practice like training and development, performance appraisal, career planning, compensation system, job design, recruitment and selection and so on. Moreover, the other variables like size, degree of expansion and previous performance are also considered to show their effects on the adoption of the HR practices. Eventually, the effects of the HR practices variables on comprised of both manufacturing and service sectors institutions functioning as public limited and private limited company forms.

\section{Research Hypothesis}

The broad objectives of this study are to explore the relationship between the uses of human resource management practices and its impact on employees 
and organizational performance. Its objective is also to compare the result obtained in the manufacturing and service sector organizations. Based on above objectives and relation, the following hypotheses are explored:

Hypothesis I: There would be an association between proper use of HRM practices and employee turnover.

Hypothesis II: There would be an association between greater use of HRM practices and labour productivity.

\section{Sources and Nature of Data}

For the purpose of fulfillment of the objectives of the research, necessary data and information were collected through primary sources especially by distributing and collecting questionnaire. Data used in this were collected from 12 manufacturing company and 23 service sector institutions. In this research, two categories of information namely employee turnover and productivity of the organizations were collected. The questionnaire was developed from the prior literature as used by Guest, 2002.

\section{Research Methodology}

This study contained the analysis of primary data collected by distributing questionnaire among selected respondents. So, this study based on descriptive, correlation, and causal analysis of the existence of various HRM practices in different organizations in Nepal. The descriptive research design was used to for the purpose of fact-finding, conceptualization, description, and operation searching for adequate information in the context of HRM practices and employee and organizational performance. This study has also adopted correlation research design to establish the relationship between HRM practices and performance. Moreover, this study also adopted causal comparative research design to determine the relationship between HRM practices and employee and organizational performance. HRM practices involved in this study were training and development, performance appraisal, career planning, employee participation, compensation, job definition and 
recruitment and selection. Further, it also presented the analysis of the employee and organizational performance variables consisting of employee turnover and productivity.

Some significant statistical and general quantitative tools were use for data analysis purpose. The statistical used for the purpose of the analysis of data were mean, standard deviation and analysis of variance. Further correlation analysis was used to show the relationship among the variables under study. The Cronbach's Alpha was measured to test the reliability of the data. F test was used to determine the goodness of fit and whether significant difference existed between the means of the variable under study or not. Since this study focused on relationship between HRM practices and employees' and organizational performance, Pearson correlation and descriptive statistics were used for analyzing numerical data. For analysis of data software programs such as SPSS 13 and Eviews 6 were used.

\section{State of HRM Practices in Manufacturing and Service Sector Organizations}

It was attempted to show the state of HRM practices in manufacturing and service sector organizations. HRM practice variables were studied based on the prior literature available in the field. The components of HRM practices studied were training and development, performance appraisal, career planning, employee participation, compensation, job definition and recruitment and selection. These components were studied from the universalistic as well as configurationally perspectives. The "universalistic" perspective alleges that certain HRM practices are always better than other and all organizations should adopt such practices on every occasion for a better performance. The "configurationally" perspective assets that multiple interdependent HR practices must cope with each other to best enhance firm performance (Wright and McMohan, 1992). 


\section{Pearson and Spearman Rho Correlation}

This study has provided correlation between two dependent variables were Employee Turnover(ET) and productivity $(\mathrm{P})$ and independent variables were Training and Development (TD), Performance Appraisal(PA), Career Planning(CP), Employee Participation(EP), Compensation(C), Job Definition(JD) and Recruitment and Selection (RS). The upper bound presented non-parametric spearman correlation coefficient and lower bound presented parametric Pearson correlation between dependent variables and independent variables. The $\mathrm{P}$-value is presented in the parenthesis * and $* *$ represents coefficient are significant at 5 percent and 1 percent level respectively.

Table 2

Pearson Correlation and Spearman Rho

\begin{tabular}{|c|c|c|c|c|c|c|c|c|}
\hline Variables & TD & PA & $\mathrm{CP}$ & $\mathrm{EP}$ & $C$ & $J D$ & RS & ET \\
\hline Training and & 1 & & & & & & & \\
\hline \multicolumn{9}{|l|}{ Development } \\
\hline Performance & $.300^{* *}$ & 1 & & & & & & \\
\hline \multicolumn{9}{|l|}{ Appraisal } \\
\hline Career Planning & $.481^{* *}$ & $.669^{* *}$ & 1 & & & & & \\
\hline Employee & $.405^{* *}$ & $.558^{* *}$ & $.616^{* *}$ & 1 & & & & \\
\hline \multicolumn{9}{|l|}{ Participation } \\
\hline Compensation & $.366^{* *}$ & $.594^{* *}$ & $.653^{* *}$ & $.436^{* *}$ & 1 & & & \\
\hline Job Design & $.314^{* *}$ & $.421^{* *}$ & $.528^{* *}$ & $.397^{* *}$ & $.487^{* *}$ & 1 & & \\
\hline $\begin{array}{l}\text { Recruitment and } \\
\text { Selection }\end{array}$ & $.404^{* *}$ & $.417^{* *}$ & $.518^{* *}$ & $.436^{* *}$ & $.441^{* *}$ & $.555^{* *}$ & 1 & \\
\hline
\end{tabular}




\begin{tabular}{lllllllll}
\hline Employee Turnover & $-.153^{* *}$ & $-.355^{* *}$ & $-.372^{* *}$ & $-.271^{* *}$ & - & $-.233^{* *}$ & $-.369^{* *}$ & 1 \\
Productivity & & & & \multicolumn{3}{c}{$.394^{* *}$} \\
& $.471^{* *}$ & $.292^{* *}$ & $.465^{* *}$ & $.366^{* *}$ & $.255^{* *}$ & $.370^{* *}$ & $.341^{* *}$ & - \\
& & & & & & & & .3 \\
& & & & & & & 03 \\
$* *$
\end{tabular}

**. Correlation is significant at the 0.01 level (2-tailed).

Above depicted table showed the Pearson correlation and Spearman Rho correlation between various HRM practices variables Training and Development (TD), Performance Appraisal (PA), Career Planning (CP), Employee Participation (EP), Compensation(C), Job Definition (JD) and Recruitment and Selection (RS), Employee Turnover(ET) and Productivity (P). The Pearson correlation showed that there are negative correlations between Employee Turnover (ET) and HRM variables TD, PA CP, EP, C, $\mathrm{JD}$, and RS and they are statistically significant at 5 percent level. However, The Pearson correlation showed that there are positive correlations between Productivity $(\mathrm{P})$ and HRM variables TD, PA CP, EP, C, JD, and RS and they are statistically significant at 5 percent level.

The correlation results suggested that there is negative association between HRM practices and employee turnover. The result also indicated that there is positive relationship between HRM practices and productivity of the organization. The result is supported by prior hypothesis set by Guest, 2002 . Furthermore, the result concluded that higher the HRM practices, higher the organizational performance.

\section{Regression Results of HRM Practices on Employee Turnover}

The regression result of effect of HRM practices consisting of variables Training and Development (TD), Performance Appraisal (PA), Career Planning (CP), Employee Participation (EP), Compensation(C), Job 
Definition (JD) and Recruitment and Selection (RS) on employee turnover. The regression result is as follows:

$\mathrm{ET}=$

$\mathrm{C}(1)+\mathrm{C}(2) * \mathrm{TD}+\mathrm{C}(3) * \mathrm{PA}+\mathrm{C}(4) * \mathrm{CP}+\mathrm{C}(5) * \mathrm{EP}+\mathrm{C}(6) * \mathrm{Comp} . \mathrm{C}(7) * \mathrm{JD}+\mathrm{C}(8) *$ RS

The $R^{2}$ is $14.32 \%$, which indicates the HRM practices explained only $14.32 \%$ of the total variance of employee turnover. Even though coefficient is insignificant, a majority of the coefficients are negative. The result suggested that there is a negative association between HRM practices and employee turnover.

\section{Regression Results of HRM Practices on Productivity}

The regression result of effect of HRM practices consisting of variables Training and Development (TD), Performance Appraisal (PA), Career Planning (CP), Employee Participation (EP), Compensation(C), Job Definition (JD) and Recruitment and Selection (RS) on productivity. The regression equation is as follows:

$\mathrm{P}=$

$\mathrm{C}(1)+\mathrm{C}(2) * \mathrm{TD}+\mathrm{C}(3) * \mathrm{PA}+\mathrm{C}(4) * \mathrm{CP}+\mathrm{C}(5) * \mathrm{EP}+\mathrm{C}(6) * \mathrm{Comp} . \mathrm{C}(7) * \mathrm{JD}+\mathrm{C}(8) *$ RS

The $R^{2}$ is $45.66 \%$, which indicates the HRM practices explained only $45.66 \%$ of the total variance of productivity. Even though coefficient is significant, a majority of the coefficients are positive. The result suggested that there is a positive association between HRM practices and productivity.

\section{Summary of the study}

This study attempted to find out the effects of some HRM practices variables on the organizational performance. The present study focuses on assessing the HRM practices in the manufacturing and service sector institutions in 
Nepal. This study also attempts to find out the relationship between the adoptions of such practices in their performance.

To achieve the objective of the study, descriptive, correlation and causal comparative research methodology was adopted. This study is based on primary data. The primary data were collected from the questionnaire addressed to the executive as well as clerical level employees of the respective organization. The status of the HRM practices in Nepalese service and manufacturing institutions seems progressive in nature and that is justified being better recruitment and selection practices in the all the organization under study. It also indicates that the Nepalese organizations are adopting broad training and development, performance appraisal, career planning, employee participation, compensation, job definition.

The analysis of data collected shows the outcomes through the study of correlation and regression which support the hypothesis that is set in this study.

- The correlation result suggested that there is a negative association between HRM practices and employee turnover. The result support the prior hypothesis set by Guest,2002. The result also indicated that there is a positive relationship between HRM practices and productivity of the organization.

- The regression result shows $R^{2}$ is $14.32 \%$ which indicates the HRM practices explained only $14.32 \%$ of the total variance of employee turnover. The result suggested that there is a negative association between HRM practices and employee turnover. However, the regression result shows $R^{2}$ is $45.66 \%$ which indicates the HRM practices explained by $45.66 \%$ of the total variance of employee productivity. The result suggested that there is a positive association between HRM practices and productivity.

Nepalese organizations in last few years are seen more conscious in performance based reward rather than traditional reward system. This study also shows the same result but the variation between the organizations by 
their types is unusual. In addition, employees may begin to understand and work towards the long term goals on the company. Incentives are shown to lead to better communication between employer and employees, increased product quality and employees being more willing to accept changes in technology. Moreover, they tend to promote reward and recognize their employees based on their operating performance. This also leads to support the fact that some of the business organizations started to give less priority to age and seniority and adopt the same policies for all in their performance evaluation management. Some Nepalese business organizations are found using team based job design that fosters the specialization as well as the synergy in the team assignment. Group work brings diversity and complete information, increase alternatives and shows legitimacy. Working in groups or team also minimizes employee turnover and maximizes their productivity as well as performance of the organization.

\section{References}

Adhikari D.R. (2005). Human Resource Management, Buddha Academic Enterprises, Kathmandu, Nepal

Agrawal, G.R. (2003). Innovative HR practices and organizational commitment: an empirical investigation. International Journal of HRM, 14,2: 175-198.

Allen, M. R. \& Wright, P. (2007).Strategic Management and HRM. In Boxall P. Purcell, J. \& Wright, P. (eds.), The Oxford Handbook of Human Resource Management. New York: Oxford University Press.

Arthur, (1992). The Link Between Business Strategy and Industrial Relations Systems in American Steel Minimills, Industrial and Labor Relations Review, 45(4), 488-506.

Aswathappa, K. (2010). Human resource management.New Delhi, McGraw Hill publication. 
Barney, J. (1991). Firm resources and sustained competitive advantage, Journal of Management, 17, 99-129.

Batt, R. (1999). Work organization, technology and performance in customer service and Batt, R. (2002). Managing customer services: Human resource practices, quit rates and sales growth. Academy of Management Journal, 45: 587-597.

Becker, B. \& Gerhart, B. (1996) 'The Impact of Human Resource Management on Organizational Performance. Progress and Prospects', Academy of Management Journal, 39(4): 779-801.

Bhattrai, M. (2008).Organization of HR functions in Nepalese banks. An unpublished M. Phil. thesis, Tribhuvan University.

Boxall, P. (1996). The Strategic HRM Debate and the Resource-Based View of the Firm.Human Resource Management Journal, 6: 59-75.

Brown, P. B. (2005). The eving role of strategic management development, Journal of Management Development, 24, 209-222.

Chand, S., J.T. Delaney, \& M.A. Huselid, (1996). The impact of human resource management practices on perceptions of organizational performance. Academy of Management Journal, 39, 949-69.

Datta D. K., Guthrie J. P., \& Wright P. M. (2005). Human resource management and labor productivity: Does industry matter? Academy of Management Journal, 48:135-145.

Dessler, G. \&Varkkey, B. (2009). Human resource management (11 ${ }^{\text {th }}$ eds). New Delhi, Pearson Publication. Development Journal, 20, 268-275.

Gautam, D. K. (2008).Strategic HRM in Nepal. Unpublished Ph.D. thesis, Kathmandu: Tribhuvan University. 
Gerhart, B. (2005). Human resources and business performance: Findings, unanswered questions, and an alternative approach. Management Review, 16, 174-185.

Guest, D. (2002). Human Resource Management, Corporate Performance and Employee wellbeing: Building the worker into HRM'. The Journal of Industrial Relations Vol.44:3 pp.335-358

Guest, D. E. (1997). Human resource management and performance: a review and research agenda. International Journal of Human Resource Management, 8: 263-276.

Harel, G.H. \& Tzafrir, S.S. (1999) The Effect of Human Resource Management Practices on the Perceptions of Organizational and Market Performance of the Firm, Human Resource Management, Vol. 38, pp.85-200.

Hersey, P. \& K.H. Blanchard, K (1993), Leadership Style: Attitudes and Behaviors, Prentice Hall, Englewood Cliffs, NJ.

Huselid, M., \& B. Becker, (1996).Methodological issues in cross-sectional research and panel estimates of the human resource - performance link, Industrial Relations, 35, 400-422.

Jackson, S.E. \& Schuler, R.S. (1995), Understanding human resource management in the context of organizations and their environments, Annual Reviews, Vol. 46, pp. 237-64.

Kelley \& Maryellen, (1996).Participative Bureaucracy and Productivity in the Machined Products Sector.Industrial Relations 35, 374-399.

Koch, M. \& McGrath, R. (1996). Improving labor productivity: human resource management policies do matter Strategic Management Journal, Vol 17 pp. 335-54 
Lawler, III, E. E. (2005). From human resource management to organizational effectiveness.Human Resource Management, 44(2), 165-169.

MacDuffie, J. P. (1995). Human resource bundles and manufacturing performance: Organizational logic and flexible production systems in the world auto industry. Industrial and Labour Relations Review, 48: $197-221$.

Ojha, S.K. (1996). Human resource management in skill development institutions of Nepal.An Unpublished Ph.D. Thesis, Kathmandu: Tribhuvan University.

Pant, P.R. (1982). Management of industrial relations in Nepal, The Nepalese Management Review, 2,1: 37-45. Pant, P.R. (1983). Industrial relation in Nepal: A comparative study of public and private undertaking in the jute industry, India: Department of Public Administration, Punjab University.

Pfeffer, J. (1994) Competitive advantage through people: Unleashing the power of the workforce. Boston: Harvard University Press research agenda'. International Journal of Human Resource Management, Vol.8, pp. 263-276.

Poudel, S.P. (2009). Effectiveness of HR functions in Nepalese commercial banks. An unpublished M. Phil. thesis, Kathmandu: Tribhuvan University. practices, Selection and Development Review, 13, 3-8.

Pradhan, A.M. (1999). Organizational climate in the public and private enterprises in Nepal.An Unpublished Ph.D. Thesis, Kathmandu: Tribhuvan University.

Pradhan, G. (1997). Management development in manufacturing public enterprises in Nepal.An Unpublished Ph.D. Thesis, Kathmandu: Tribhuvan University. 
Ramaswamy, E.A., \& F.B. Schiphorst, (2000). Human resource management, trade unions and empowerment: Two cases from India, International Journal of Human Resource Management, 11(4): 664-80.

Storey, J. (1995).Managing Human Resources: Preparing for the 21st Century. New Delhi: Beacon Books.

Ulrich, D. (1997). Measuring human resources: An overview of practice and a prescription for results, Human Resource Management 36(3),30320.

Walton, R..E. (1985). Toward a strategy of eliciting employee commitment based on policies of mutuality. In R. E. Walton \& P. R. Lawrence (Eds.), Human resource management: Trends and challenges, Boston: Harvard Business School Press. 116

Youndt, M., S., Snell, J., Dean, \& D. Lepak, (1996).Human resource management, manufacturing strategy, and firm performance.Academy of Management Journal,39, 836-866. 